\title{
Analysing indicators of industry convergence in four probiotics innovation value chains
}

\author{
S. Bornkessel ${ }^{1 *}$, S. Bröring ${ }^{2}$ and S.W.F. Omta ${ }^{3}$ \\ ${ }^{1}$ University of Applied Sciences, Oldenburger Landstr. 62, 49090 Osnabrück, Germany; ${ }^{2}$ University of Bonn, Meckenheimer Allee \\ 174, 53115 Bonn, Germany; ${ }^{3}$ Management Studies Group, Wageningen University, P.O. Box 8130, 6700 EW Wageningen, the \\ Netherlands; s.bornkessel@hs-osnabrueck.de
}

RESEARCH ARTICLE

\begin{abstract}
The relevance of cross-industry innovation has increased in recent decades with a growing number of inter-industry fields emerging on the borderline between formerly distinct industries. The aim of this paper is to analyse industry convergence in four probiotics innovation value chains based on the following indicators: cross-industry relationships along the innovation value chain as well as knowledge, technological, regulatory and competence convergence. In so doing, the study delivers a framework of indicators for scrutinising industry convergence processes. In order to identify industry convergence, we analyse companies in the converging area of foods and drugs based on products containing the four bacteria strains: Lactobacillus caseii DN 114001, Bifidobacterium lactis Bb12, Lactobacillus acidophilus LA5 and Lactobacillus rhamnosus. Hence, the commercial availability of the strains on the market serves as a selection criterion. Altogether 12 companies stemming from four industrial backgrounds, food and agriculture (5), pharmaceutics (5), chemistry (1) and personal care (1), as well as one research organisation are identified. Cross-industry relationships occur along the innovation value chains of the four strains. Clear signs of knowledge and technological convergence are found as companies are not only publishing and patenting in the usual area of their own industrial field but also in the area of other industrial fields. Companies with different industrial backgrounds show activities in obtaining health claims indicating regulatory convergence. Companies' competence bases seem to converge as companies with different industrial backgrounds are involved in acquisitions, licencing agreements and strategic alliances (competence convergence). We contribute to the existing body of literature by assessing industry convergence from an innovation value chain perspective with a set of indicators reflecting the intensity of industry convergence. This framework of indicators stemming from literature has not yet been used in a combined comprehensive analysis. Furthermore, we tried to show the characteristics of strategic types driving industry convergence in probiotics.
\end{abstract}

Keywords: industry convergence, cross-industry innovation, functional ingredient, probiotics

Copyright: $\odot 2014$ S. Bornkessel et al. This is an open-access article distributed under the terms of the Creative Commons Attribution License, which permits unrestricted use, distribution, and reproduction in any medium, provided the original author and source are credited.

\section{Introduction}

The relevance of cross-industry innovation has increased in recent decades with a growing number of inter-industry fields emerging on the borderline between formerly distinct industries (e.g. Bröring et al., 2006; Farber and Baran, 1977; Hacklin, 2008; Henderson and Clark, 1990). This phenomenon of industry convergence is defined in multifaceted terms in the extant literature but follows the common idea summarised by the Organisation for Economic Co-operation and Development 'the blurring of technical and regulatory boundaries between sectors of the economy' (OECD, 1992). With the blurring of boundaries between hitherto distinct industry sectors, the importance of cross-industry relationships along innovation value chains increases (Enkel and Gassmann, 2010). Concurrently, further industry convergence indicators like knowledge or competence convergence can be used to set up a framework of indicators analysing industry convergence processes.

Convergence of computing and telecommunication was first mentioned in the late 1970s (Farber and Baran, 1977). With the growing interest in this research field, numerous publications can be found focussing on the overlapping industry fields of information and communication technology (e.g. Bröring and Leker, 2007; Henderson and Clark, 1990; Katz, 1996; Prahalad, 1998). A recent example of convergence can be found in the nutraceuticals and 
functional foods sector that emerges on the borderline between the food and pharmaceutical industries (Bröring et al., 2006). Product examples of this emerging field are, for instance, cholesterol-lowering margarine with phytosterols and products benefiting the immune system like probiotics (Verhagen et al., 2010). Probiotics in particular represent a growing market segment (Stanton et al., 2001). Probiotics are defined as 'live microorganisms, as they are consumed in adequate numbers confer[ring] a health benefit on the host' (Stanton et al., 2001). Following this definition, the microorganisms - different strains of bacteria - are the value-generating ingredients of probiotic products.

Beyond that, the aim of this study is to analyse industry convergence in probiotics innovation value chains. Therefore, we assess industry convergence with distinct indicators, concurrently relating these indicators to the innovation value chain perspective. Thereby, we follow an exploratory approach to derive propositions. Consequently, we try to answer the following research question:

\section{RQ: How can industry convergence be assessed from an innovation value chain perspective?}

The remainder of this paper is structured as follows. In section two, we focus in detail on industry convergence showing different indicators to analyse industry convergence derived from the literature. In so doing, we provide an indepth description of the indicators of industry convergence as follows: cross-industry relationships along the innovation value chain, knowledge, technological, regulatory and competence convergence. Section three encompasses the sample and methods of the study. In section four, our results are presented starting with the identification of the companies active in the area of probiotics, followed by the companies' indicators of industry convergence. Finally, we will discuss our findings and their implications for academics and practitioners alike, before concluding with an outlook on future research possibilities.

\section{Indicators of industry convergence}

\section{Cross-industry relationships along innovation value chains}

In many studies the industry convergence concept is primarily associated with technological convergence. However, it is a multifaceted phenomenon which should not be reduced to the technological level (Borés et al., 2003; Nyström, 2008). Moreover, dimensions of industry convergence are discussed as a process rather than a steady state (e.g. Bröring, 2005; Curran, 2010; Curran et al., 2010;
Hacklin, 2008). One possibility is the description of the consecutive steps, science, technology, market and industry, as an idealised time series of events leading to a complete convergence of two hitherto distinct industry sectors. The initial step implies that distinct scientific disciplines begin to cite each other in interaction with first collaborations of scientific disciplines. Decreasing the distance between applied sciences and technology development is defined as the second step. The subsequent emergence of new productmarket combinations is called market convergence. The final step in industry convergence incorporates fusion of firms or industry segments (Curran et al., 2010; Hacklin, 2008).

The research and development phase within value chains is commonly defined as the discovery of new knowledge, which is then used to create new and improved products (Kaplinsky and Morris, 2000). Furthermore, the first two phases of the innovation value chain introduced by Hansen and Birkenshaw focus on idea generation and conversion (Hansen and Birkinshaw, 2007). This corresponds firstly to science convergence with the discovery of knowledge from neighbouring publishing disciplines and secondly, technological convergence with the application of a technology (Figure 1). The commercialisation phase within value chain analysis respectively the idea diffusion phase within innovation value chains is the step of the delivery to final consumers (Hansen and Birkinshaw, 2007; Kaplinsky and Morris, 2000), which overlaps with the market and industry convergence step where new productmarket combinations arise (Bröring, 2005). Therefore, the consideration of the innovation value chain in the context of industry convergence is of great importance as the partners within the innovation value chain are still the most important sources of knowledge used to develop inventions (Enkel and Gassmann, 2010; Giuri et al., 2007). In the context of industry convergence, these partners stem from different industrial backgrounds reflected by crossindustry relationships. Beyond that, the first proposition focussing on the first indicator of industry convergence can be derived:

P1: If probiotics innovation value chains converge, companies will show cross-industry relationships along the innovation value chain.

Based on the literature focussing on industry convergence processes, further indicators beside the cross-industry relationships along the innovation value chain can be identified, for instance regulatory or competence convergence (e.g. Bröring, 2005; Curran, 2010; Gambardella and Torrisi, 1998; Katz, 1996; Yoffie, 1997). In the following sections the indicators of industry convergence based on 


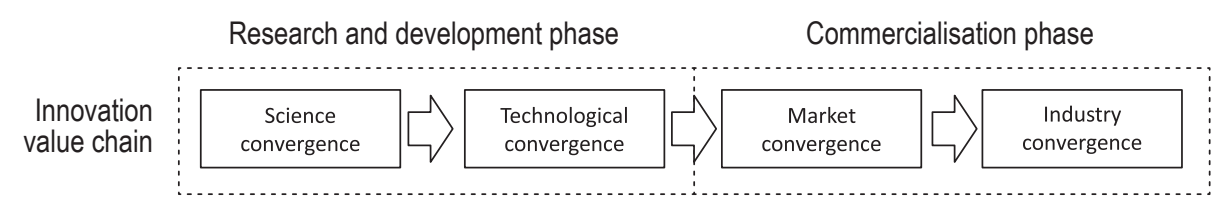

Figure 1. Industry convergence along the innovation value chain.

the aforementioned consecutive steps are discussed first, followed by the indicators independent from the procedural view.

\section{Knowledge convergence}

In the literature, knowledge convergence is also called 'science convergence' (refer to the previous discussion on the consecutive steps of industry convergence and for instance, Hacklin, 2008) underlining the importance of knowledge as a basis for convergence processes (Guilhon, 2001; Pennings and Puranam, 2001). Following the idealised time series of industry convergence, the first step encompasses knowledge convergence implying that distinct scientific disciplines begin to cite each other (Curran, 2010; Curran et al., 2010). Furthermore, collaborations of scientific disciplines (i.e. collaborations of different departments of one university or different universities) are part of the initial step of convergence. Based on this diversification, competence gaps might be closed. Moreover, scientific communities start to publish not only in their own research area but also in other areas. Therefore, the subject areas of the scientific publications (e.g. topics) differ from their own research area. Beyond that, knowledge convergence can be measured by an elaboration of scientific publications and their subject areas (Bornkessel et al., 2011; Curran et al., 2010). These analyses encompass the elaboration of the industrial background of the publishing parties as well as the publications' scientific subject areas. This leads to the second proposition:

\section{P2: If probiotics innovation value chains converge, companies will show knowledge convergence.}

\section{Technological convergence}

Likewise the multifaceted definitions of industry convergence in general, technological convergence is variously described and defined within the literature (see, for instance, Kim and Kim, 2012; Nyström, 2008). In some studies, technological convergence is put on the same level as industry convergence (Borés et al., 2003). This might be due to the fact that the general idea of convergence goes back to the overlapping of technologies (Rosenberg, 1976; Stieglitz, 2002). However, there are also attempts to clearly delineate technological convergence from the general industry convergence concept (Katz, 1996). Following a definition by Hacklin (2008), technological convergence:

denotes the transition of knowledge convergence into a potential for technological innovation, allowing inter-industry knowledge spill-overs to facilitate new technological combinations. (Hacklin, 2008).

Thereby, technological convergence is the translation of science and knowledge convergence into technological innovation (Curran, 2010; Hacklin, 2008) or in other words knowledge is the underlying basis for technological convergence (Kim and Kim, 2012) ${ }^{1}$. In line with the idea of the convergence of technologies being a driver of industry convergence, the underlying technological platforms of the formerly distant industry sectors become more alike (Fai and Von Tunzelmann, 2001; Gambardella and Torrisi, 1998). Following this reasoning one can assume that application areas (as detailed in patents) of the commonly used technology platforms are becoming increasingly broad as they build the basis of product development for two different industries. Furthermore, this serves as an indicator of companies' approaches to closing the resulting competence gaps.

Several studies have already used patents to scrutinise and anticipate industry convergence on the technological level (Bornkessel et al., 2011; Bröring, 2005; Curran, 2010; Curran et al., 2010; Daim et al., 2006; Ernst, 1998; Liu and Shyu, 1997). Patent analyses encompass the elaboration of the industrial background of the patenting companies as well as the patents' application areas. Thereby, subject areas describe the topic of the patent. Consequently, the third proposition can be deduced:

\section{P3: If probiotics innovation value chains converge, companies will show technological convergence.}

\footnotetext{
${ }^{1}$ As knowledge is discussed as a basis for science as well as for technological convergence it becomes clear that a delineation of both constructs is characterised by blurring boundaries; for a further discussion see for instance Curran (2010).
} 


\section{Market convergence}

When considering market convergence, the central idea is that formerly distinct industrial areas start to produce similar products in an emerging field of new approaches (Gambardella and Torrisi, 1998). Given that these products combine different functions and underlying technologies, convergence on the market level can be observed (Bröring, 2005). In the area of probiotics, these hybrid products are in the form of food and dietary supplements like dairy products and baked products. Such probiotic products are claimed to modulate gut microbial composition, thereby leading to improved gut health (Stanton et al., 2001). They are hybrid products as they show the appearance of traditional food products originating from the food industry and concurrently deliver a health benefit beyond the nutritional value incorporating functions from drugs rooted in the pharmaceutical industry.

As the aim of this study is to explore industry convergence in four probiotics innovation value chains, we use the presence of market convergence as the chosen criterion for our research objects assuming a further developed industry convergence process. Accordingly, we identify the companies based on the available probiotic products on the market considering the specific probiotic strains.

\section{Regulatory convergence}

In addition to the consecutive steps of knowledge (resp. science), technological and market convergence leading to industry convergence, regulatory convergence appears to be highly important especially in the case of probiotics because of the on-going process of changing regulations for functional foods. Regulatory aspects are highly industryrelated as distinct legislation is applicable to different products. Regulatory convergence can be defined as 'the growing similarity of institutional frameworks, policy approaches and outcomes in the field of regulatory politics' (Falkner and Gupta, 2009). Based on this definition, regulatory convergence encompasses inter alia the emergence of new legislative texts or standards. This might be due to the changing industrial environment or, indeed, the regulation could be triggering industry convergence (Bröring, 2005). But regulation is mostly discussed as a barrier to convergence (Katz, 1996). In the case of nutraceuticals and functional foods, the most prominent example of an emerging legislative text in Europe is the health claim regulation (EC No. 1924/2006). The emergence of this regulation encompassing health-related issues for nutritional products, e.g. the application of clinical trials to food products, shows tendencies of an on-going regulatory convergence process. Furthermore, the application of the regulation by different industry sectors can be used as an indicator to identify convergence in regulation. Therefore, companies' activities in obtaining health claims (and related to this, the conducting of clinical trials to file dossiers to be evaluated by the European Food Safety Authority) serves as an indicator for convergence in regulation. Therefore, the fourth proposition can be derived:

\section{P4: If probiotics innovation value chains converge, companies will show convergence in regulatory compliance.}

\section{Competence convergence}

Concurrently with the upcoming versatility and the need for different competences, the stretching of resources to serve the adjacent industry, resp. emerging inter-industry segment, might lead to competence gaps in the firms involved (Pennings and Puranam, 2001). Therefore, the literature on industry convergence processes also focuses on the role of individual business actions (Curran, 2010) to deal with the industry convergence related challenges (Katz, 1996; Yoffie, 1997). Therefore, the second indicator beside the consecutive steps of industry convergence can be summarised by the term 'competence convergence'. This concept encompasses companies' strategic actions in terms of competence activities to close competence gaps or in other words the internalisation of assets (Gambardella and Torrisi, 1998). One way of meeting the challenge of upcoming competence gaps is the internalisation of external assets through the acquisition of companies (Bower, 2001; Gambardella and Torrisi, 1998). Furthermore, competence gaps can be closed through licencing agreements as well as strategic alliances. Therefore, competence convergence is reflected by the analyses of mergers and acquisitions, licencing agreements and strategic alliances assuming that companies are sourcing-in the missing competence. Thus, the competence base of hitherto distinct industry sectors starts to look similar. This leads to the fifth proposition:

\section{P5: If probiotics innovation value chains converge, companies will show competence convergence.}

Furthermore, a distinction can be made between technologydriven input-side convergence and market-driven outputside convergence (Bröring, 2005) refining the general concept of demand-side and supply-side convergence processes (Malhorta and Gupta, 2001). In this scenario, the technology-driven input-side convergence evolves from new technologies which are applied across distinct industry sectors, whereas market-driven output-side convergence evolves from the customers changing the functions of a 
product by adding or dropping some options for use (Bröring, 2005). Both concepts can be of a substitutive or a complementary nature (Bröring, 2005). By that means, a substitutive process leads to industry fusion; two distinct industry sectors become one $\left({ }^{\prime} 1+1=1^{\prime}\right)$. A substitutive relation implies that the replacement of the conventional approaches proceeds. A complementary process is highlighted by the creation of a new value chain between the old ones leading to a new inter-industry segment $\left(' 1+1=3^{\prime}\right)$. The case of nutraceuticals and functional foods is already defined in literature as a complementary process (e.g. Bröring and Cloutier, 2008). The study's example of probiotics belongs to the functional food sector, therefore might show a complementary process. The engagement of companies in the new emerging field is based on their individual strategic decisions, as the new sector is complementary to the existing ones. If companies aim at the new sector, their activities along the value chain can be divided into three categories: (a) technology developers; (b) technology-intense product developers; and (c) product developers using existing technologies (Bröring and Cloutier, 2008). Firstly, technology developers are characterised by new science-driven technology developments without a direct application to the consumer market. Secondly, new technology developments associated with direct use to form a consumer product are defined as technologyintense product developers. Thirdly, product developers using existing technologies show new consumer product developments with the intent of using existing external technologies (Bröring and Cloutier, 2008).

\section{Methods}

\section{Research framework}

Against this theoretical background, the study at hand uses a mixed-method approach (Johnson and Onwuegbuzie, 2004; Latcheva, 2011) to analyse industry convergence in four probiotics innovation value chains using quantitative and qualitative data. We firstly identify the companies in the area of probiotics active in the different steps of the innovation value chain based on the products they sell in the market (market convergence). In the following, the unit of analysis are these identified companies. Concurrently, their cross-industry relationships are depicted showing the first indicator of industry convergence. Secondly, we show the further industry convergence indicators of the identified companies: knowledge, technological, regulatory and competence convergence. Competence convergence shows a relationship with the other three indicators as the resulting competence gaps might be closed through industry convergence related behaviour on all levels. We follow the structure shown in Figure 2 depicting an overview of the measures and data sources used for the industry convergence indicators. The four indicators for innovation value chains as well as knowledge, technological and regulatory convergence are measured focussing on probiotics, whereas the indicator of competence convergence covers all strategic business activities of each company.

The occurrence of cross-industry relationships is used to explore proposition P1 as first indicator of industry convergence. Bibliometric analyses of scientific publications and patents deliver quantitative measures exploring the propositions P2 and P3. Qualitative data is generated by analyses of the news reports regarding health claims exploring proposition $\mathrm{P} 4$. The qualitative and quantitative analyses of competence convergence present a measure to explore proposition P5. The analysis of these industry convergence indicators is further described in the following subsections summarising the analyses of scientific publications and patents.

\section{Identification of companies and their cross-industry relationships along innovation value chains}

Following a qualitative approach, the creation of a list of probiotic strains currently available on the global market is established based on the report 'Global Probiotics Market' by MarketsandMarkets in 2010 (www.marketsandmarkets. com) and scientific literature about probiotics (e.g. Siezen and Wilson, 2010) as well as further desk research. The focus

\begin{tabular}{|c|c|c|c|c|c|c|c|}
\hline \multirow{3}{*}{$\begin{array}{r}\text { Industry } \\
\text { convergence } \\
\text { indicators }\end{array}$} & \multicolumn{4}{|c|}{ Focus on probiotics } & \multicolumn{3}{|c|}{ On company level } \\
\hline & $\begin{array}{c}\text { Innovation value } \\
\text { chain }(P 1)\end{array}$ & $\begin{array}{c}\text { Knowledge } \\
\text { convergence (P2) }\end{array}$ & $\begin{array}{c}\text { Technological } \\
\text { convergence (P3) }\end{array}$ & $\begin{array}{c}\text { Regulatory } \\
\text { convergence (P4) }\end{array}$ & \multicolumn{3}{|c|}{ Competence convergence (P5) } \\
\hline & 5 & 5 & 5 & 5 & \multicolumn{3}{|c|}{ 5 } \\
\hline \multirow[t]{2}{*}{ Measure } & $\begin{array}{l}\text { Cross-industry } \\
\text { relationships }\end{array}$ & Scientific publications & Patents & $\begin{array}{l}\text { Health claim } \\
\text { applications }\end{array}$ & $\begin{array}{c}\text { Mergers \& } \\
\text { acquisitions }\end{array}$ & Licencing agreements & Strategic alliances \\
\hline & 5 & 5 & 5 & 5 & 5 & 5 & 5 \\
\hline Data sources & $\begin{array}{l}\text { Literature / desk } \\
\text { research }\end{array}$ & Thomson Innovation & Thomson Innovation & $\begin{array}{c}\text { LexisNexis/ } \\
\text { nutraingredients }\end{array}$ & LexisNexis & LexisNexis & LexisNexis \\
\hline
\end{tabular}

Figure 2. Overview of study structure including the related measures and data sources. 
in this paper lies on bacteria strains, which can currently be found in commercial dairy products. Hence, the commercial availability of the strains on the market serves as a selection criterion and depicts the dimension of market convergence. We have chosen four strains based on the market share of end products. The four bacteria strains are Lactobacillus caseii DN 114001, Bifidobacterium lactis Bb12, Lactobacillus acidophilus LA5 and Lactobacillus rhamnosus. These strains are used to identify the active companies. Furthermore, based on the above data sources, their general position in the innovation value chain (research and development, B2B and B2C commercialisation) as well as their cross-industry relationships is determined ${ }^{2}$. The industrial background of the manufacturers is categorised according to Standard Industrial Classification codes, a United States government system that indicates the company's type of business (U.S. Securities and Exchange Commission, 2011).

\section{Bibliometric analyses - knowledge and technological convergence}

In line with earlier research, stressing the importance of scientific literature and patent analysis for analysing the first steps of industry convergence, we scrutinise the companies of the probiotics innovation value chains regarding their scientific publications and patents in the area of probiotics. We analyse a part of the dataset gathered to study industry convergence in probiotics in general (Bornkessel et al., 2012). We evaluate a period between 1990 and 2009 using the Thomson Innovation software tool. Thomson Innovation is a platform that facilitates analysis of intellectual property, scientific literature and business data (www.thomsoninnovation.com). It draws upon the Derwent World Patents Index, a database, which categorises patent documents using a classification system for all technologies. To classify scientific publications as well as patents, they are scrutinised on their application areas using the keywords in the title and abstract of each publication. By that means, the considered application areas are 'pharmaceutics', 'personal care' and 'food and agriculture', whereas the remaining scientific publications, which do not fit into one of these groups, are summarised in the category 'other', for instance general machinery or technical equipment.

\section{Analysis of health claim applications - regulatory convergence}

Based on the literature for analysing regulatory convergence, we analyse the health claim submission activity of the companies in the probiotics innovation value chain. As

\footnotetext{
${ }^{2}$ This categorisation is based on Boschloo (2011).
}

there is no publicly available data on the applicants of health claims, we conduct a desk search from three angles: firstly, we scrutinise the legislative texts summarised by LexisNexis, secondly, we focus on the news reports also using LexisNexis and thirdly, we conduct a search on the website nutraingredients. For all three analyses, we used a time-frame from 2006 to 2013 as the European health claim submission became law in 2006 and the on-going process of evaluating health claim submissions has not yet finished.

\section{LexisNexis legislative texts}

Using a qualitative approach, we elaborate a period between 2006 and 2013 using the search mask 'legislative texts' on LexisNexis focusing on European law. LexisNexis is a global provider of content-enabled workflow solutions (www.lexisnexis.com/uk/nexis/home/home.do) using different global databases. The database on legislative texts encompasses full-text, English language EC/EU Treaties, Legislation, Preparatory Documents, National Provisions Implementing Directives, Parliamentary Questions, EFTA, and other documents as provided by EUR-Lex - the computerised documentation system on Community law, which the EU institutions makes available to their officials and the public.

\section{LexisNexis news reports}

Following a qualitative approach, we elaborate a time-frame between 2006 and 2013 using the search mask 'news reports' using the following setting: major European publications.

\section{News search on nutraingredients}

We conduct a desk research on the website nutraingredients with the advanced search tool using the term 'health claim' and the name of the company with the setting that all terms must be included in the search results. We include all types of information sources. The news information on the website is based on a scan of all available scientific, technical and industry sources as well as a search of previously unpublished material, primary data and expert opinions (www.nutraingredients.com/info/about-us).

\section{Competence convergence}

Based on the literature for analysing competence convergence, we conduct a search of companies' strategies to close competence gaps from three angles: firstly, mergers and acquisitions, secondly, licencing agreements and thirdly, strategic alliances. Firstly, using a quantitative approach, we evaluate a time-frame between 1990 and 
2013 using the search mask 'mergers and acquisitions' of LexisNexis employing an analysis for every company of the probiotics value chain using the Mergerstat M\&A database. This database provides detailed information on mergers, acquisitions and divestitures that are publicly announced for over 30 years. Secondly, following a qualitative approach, we analyse the news reports considering the licencing agreements and strategic alliances in case of probiotics.

\section{Results}

\section{Identification and categorisation of companies active in the global probiotics sector}

The qualitative approach to identifying active companies in the area of the four probiotic strains delivers a total of 12 companies and one research organisation. The companies stem from the following four industrial backgrounds: food and agriculture (5), pharmaceutics (5), chemistry (1) and personal care (1). The research organisation focuses its studies on the health care sector. Therefore, within the following results parts in Figure 3 to Figure 6 showing the innovation value chains of the four bacteria strains, the research organisation is categorised as stemming from the pharmaceutical sector.

Companies' characteristics like sales, employees and the history of a company influence all their activities along the innovation value chain as well as strategic action in the context of industry convergence. Table 1 gives an overview of the identified companies based on publicly available data to be considered when interpreting further results. Furthermore, the company's activity in the four bacteria strains is listed.

According to the company characteristics showing a dominance of the food and agricultural sector, we will focus in the following results sections firstly on the food and agricultural sector and secondly, summarised in one group the pharmaceutical, chemical and personal care sector.

Table 1. Company characterisation based on sales, employees and history (data based on LexisNexis) as well as the company's activity in the four bacteria strains (data based on Boschloo, 2011)

\begin{tabular}{|c|c|c|c|c|c|c|c|c|}
\hline \multirow{2}{*}{$\begin{array}{l}\text { Industrial } \\
\text { background of } \\
\text { company }\end{array}$} & \multirow[t]{2}{*}{ Coding $^{1}$} & \multirow[t]{2}{*}{ Sales (2012) } & \multirow[t]{2}{*}{ Employees } & \multirow[t]{2}{*}{ History } & \multicolumn{4}{|c|}{ Activity in bacteria strains } \\
\hline & & & & & 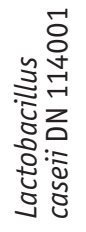 & 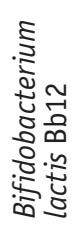 & 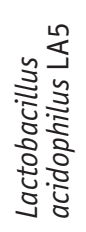 & 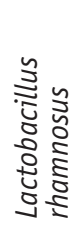 \\
\hline Food and & $1-1$ & $\$ 99,498,193,520$ & 328,00 & 1866-to date & & $x$ & & \\
\hline \multirow[t]{4}{*}{ agriculture } & $1-2$ & $\$ 28,000,000,000$ & 102,401 & 1966-to date & $x$ & & & \\
\hline & $1-3$ & $\$ 17,700,000,000$ & 41,000 & 1928-to date & & $x$ & $x$ & \\
\hline & $1-4$ & $\$ 2,691,918,649$ & 4,447 & 1905-to date & & & & $x$ \\
\hline & $1-5$ & $\$ 648,726,000$ & 1,330 & 1992-to date & & $x$ & & \\
\hline \multirow[t]{5}{*}{ Pharmaceutics } & $2-1$ & $\$ 3,330,963,048$ & 4,818 & 1907-to date & & & & $x$ \\
\hline & $2-2$ & No data available & 2,416 & 1957-to date & & $x$ & & \\
\hline & $2-3$ & No data available & No data available & $\begin{array}{l}\text { Patent in 1983; } \\
\text { no further data available }\end{array}$ & & & $x$ & \\
\hline & $2-4$ & No data available & No data available & $\begin{array}{l}\text { Patent in } 1989+1991 \\
\text { no further data available }\end{array}$ & & & $x$ & $x$ \\
\hline & $2-5$ & No data available & No data available & No data available & & & $x$ & \\
\hline Chemistry & $3-1$ & $\$ 124,089,120$ & 2,450 & 1874-to date & & $x$ & $x$ & \\
\hline Personal care & $4-1$ & $\$ 30,238,612,859$ & 68,886 & 1909-to date & & $x$ & & \\
\hline $\begin{array}{l}\text { Research } \\
\text { organisation }\end{array}$ & $5-1$ & No data available & No data available & 1887-to date & $x$ & $x$ & & \\
\hline
\end{tabular}

${ }^{1}$ The first digit of the coding indicates the industrial background of the company and the second digit is used as continuous numbering whereas the order is based on sales in 2012 (if applicable). 


\section{Innovation value chains}

The following figures (Figure 3-6) show the different innovation value chains for the four bacteria strains. In general, the value chains for the different bacteria strains are different according to the number of companies, the industrial backgrounds involved and the cross-industry relationships. In the following, we will describe each innovation value chain in detail from a company-based view.

\section{Lactobacillus caseii DN 114001}

The innovation value chain of Lactobacillus caseii DN 114001 is rather simple with the joint development of a research organisation focusing on the health care sector (5-1) and a company stemming from the food and agricultural sector (1-2). The joint research might be due to missing competences within the agrifood company in the health care sector and, therefore, a closing of the competence gaps has arisen through industry convergence.

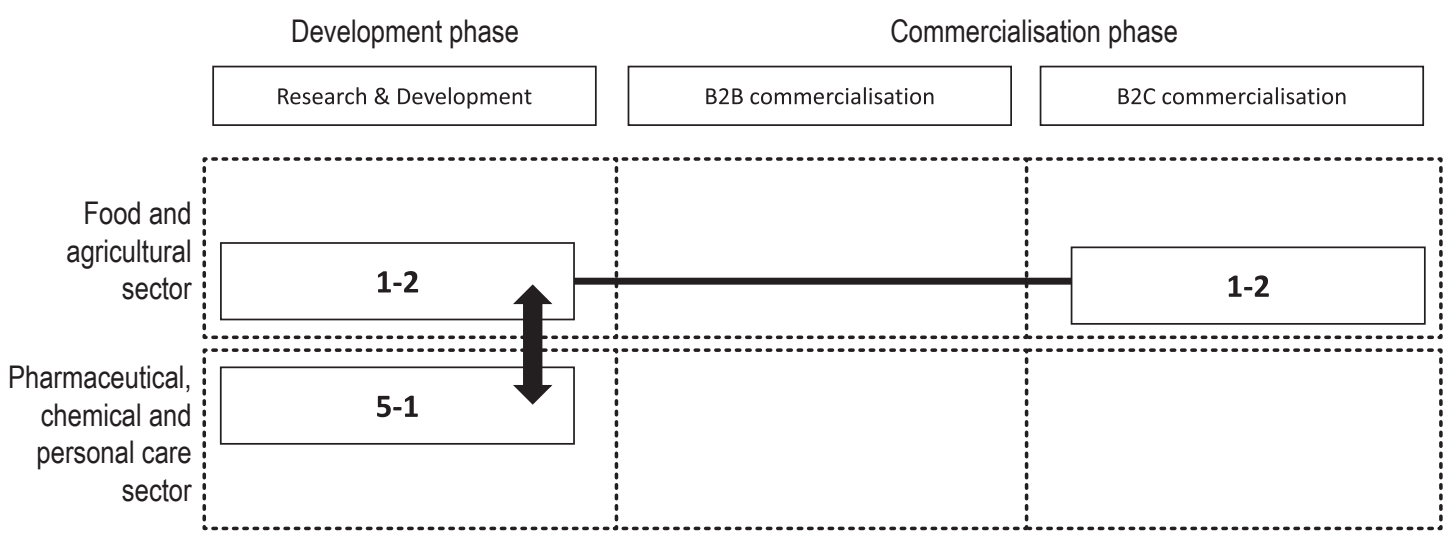

Figure 3. Innovation value chain of Lactobacillus caseii DN 114001. Arrows show the cross-industry relationships and the line between two boxes connects the steps fulfilled by one company.

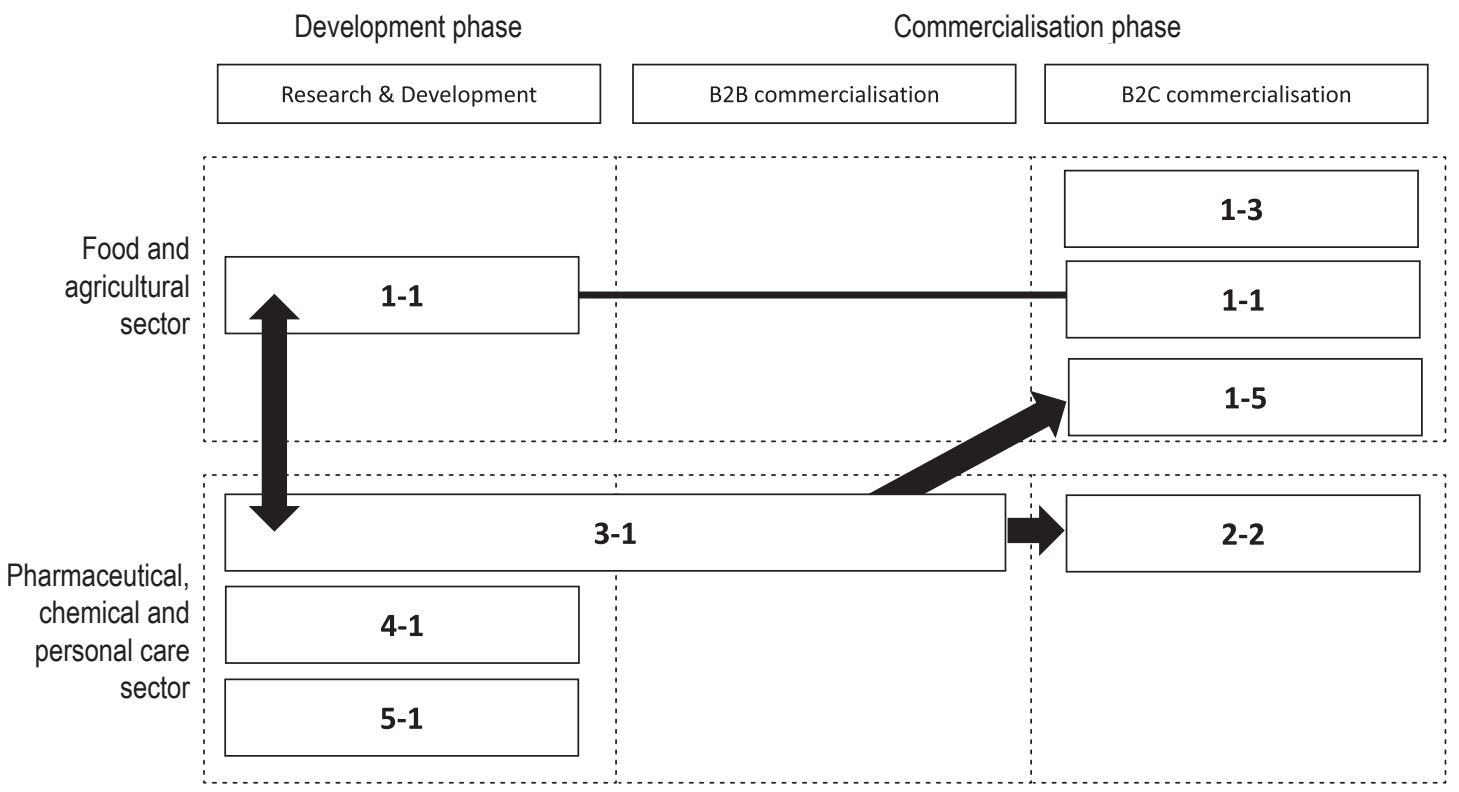

Figure 4. Innovation value chain of Bifidobacterium lactis Bb12. Arrows show the cross-industry relationships and the line between two boxes connects the steps fulfilled by one company. 
After the joint development, the company processes and commercialises the bacteria strain. The agrifood company is responsible for the research and development as well as the commercialisation phase, whereas the research organisation is only involved in the development of the probiotic product.

\section{Bifidobacterium lactis Bb12}

The innovation value chain depicting the relationships for the second bacteria strain B. lactis Bb12shows crossindustry relationships vertically and horizontally between the chemical company (3-1) undertaking the two steps of development and B2B commercialisation and two companies stemming from food and agriculture (1-1; 1-5) and one from pharmaceutics (2-2). Thereby, the horizontal cross-industry relationship between the chemical (3-1) and agrifood company (1-1) shows joint research (development layer) whereas the two other vertical relationships show buyer-supplier relationships. The research organisation (5-1) as well as the personal care company (4-1) show activities on the development layer without a relation to other companies or a further vertical integration in the value chain. One agrifood company (1-3) takes up the position of B2C commercialising without activity on the development layer.

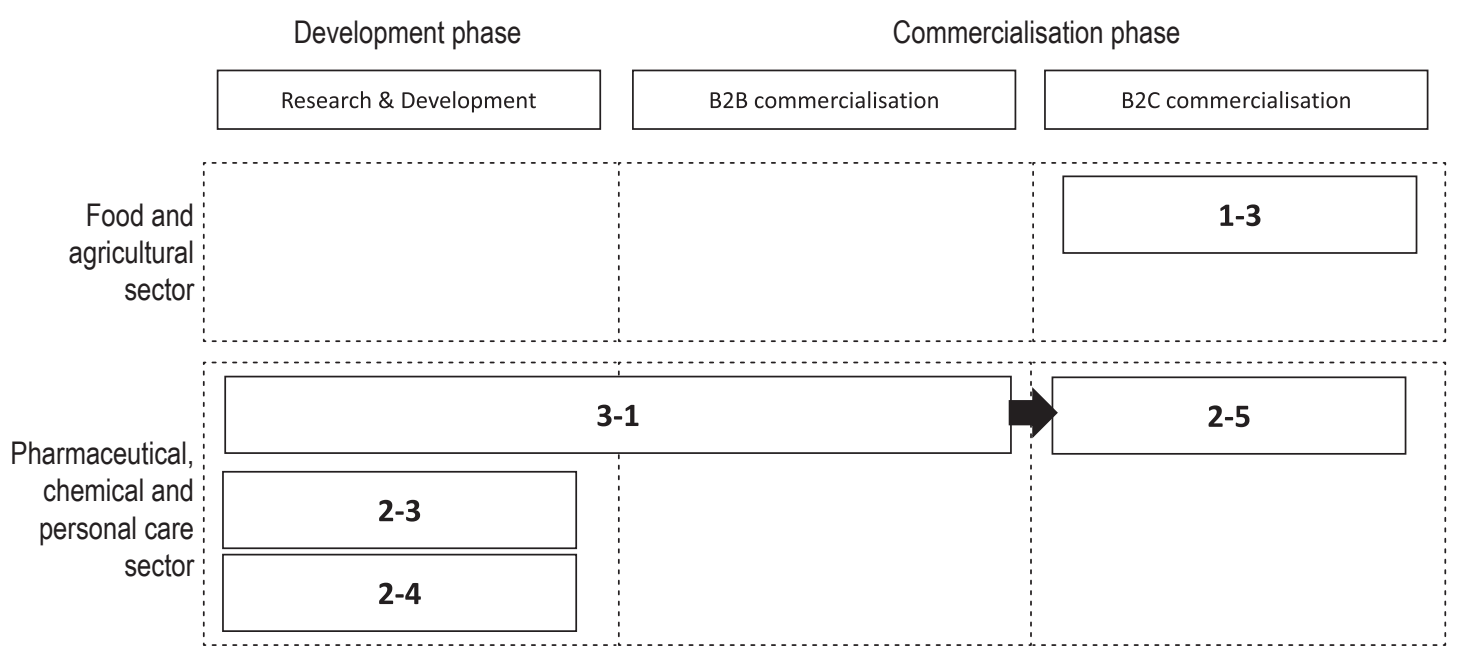

Figure 5. Innovation value chain of Lactobacillus acidophilus LA5. Arrows show the cross-industry relationships and the line between two boxes connects the steps fulfilled by one company.

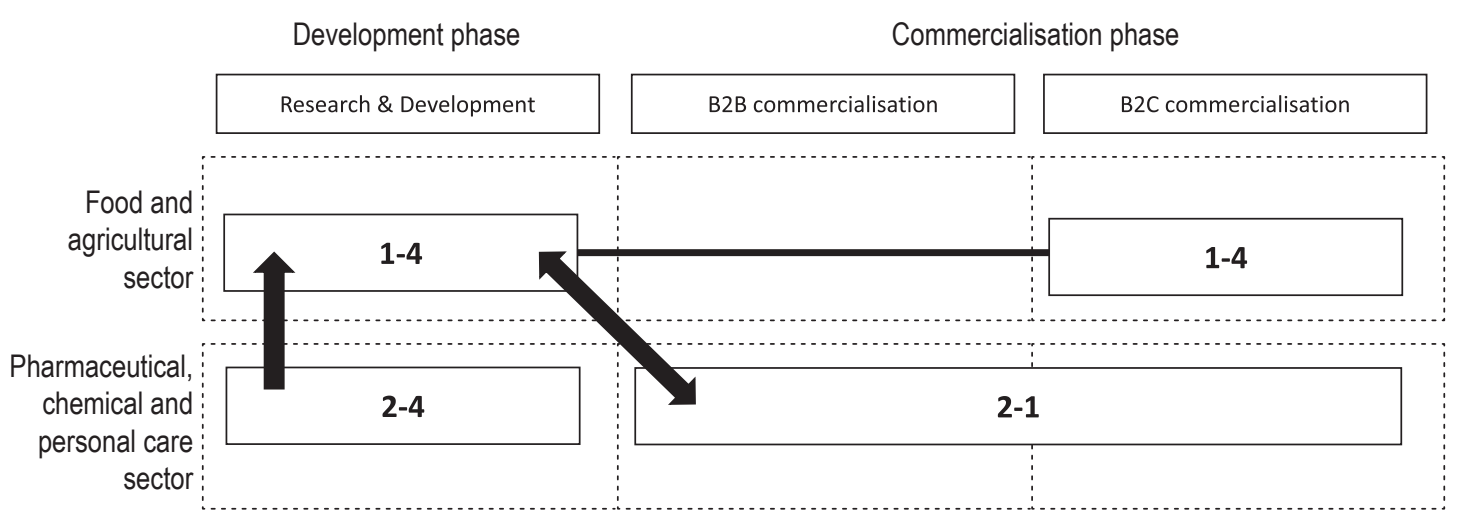

Figure 6. Innovation value chain of Lactobacillus rhamnosus. Arrows show the cross-industry relationships and the line between two boxes connects the steps fulfilled by one company. 


\section{Lactobacillus acidophilus LA5}

The innovation value chain of Lactobacillus acidophilus LA5 shows one vertical cross-industry relationship between the chemical company (3-1) and a pharmaceutical company (2-5). Along the innovation value chain, the chemical company fills the positions for development and $\mathrm{B} 2 \mathrm{~B}$ commercialisation whereas the pharmaceutical company is responsible for the later $\mathrm{B} 2 \mathrm{C}$ commercialisation. This association shows a buyer-supplier relationship. On the development layer two pharmaceutical companies (2-3; 2-4) can be found showing no further integration along the innovation value chain. One agrifood company (1-3) fills the position on the $\mathrm{B} 2 \mathrm{C}$ commercialisation layer - also with no further integration along the innovation value chain.

\section{Lactobacillus rhamnosus}

Three companies - one from the food and agricultural sector (1-4) filling the positions for development and B2C commercialisation and two from pharmaceutics $(2-1 ; 2-4)$ - build up the innovation value chain regarding the bacteria strain Lactobacillus rhamnosus. Although the agrifood company is active on the development layer there is a vertical buyer supplier relationship with the pharmaceutical company (2-4) active on the development layer. Furthermore, there is horizontal co-operation between the agrifood company (1-4) and the second active pharmaceutical company (2-1).

In general, the food and agricultural sector shows activity for all four bacteria strains. All industrial backgrounds are active for the B. lactis Bb12 strain. The companies stemming from the pharmaceutical sector show the second highest activity in terms of involvement in the steps of development and commercialisation on B2C of the four bacteria strains. Summarising the results from the innovation value chains of these four bacteria strains, cross-industry relationships occur in all four cases at different stages of the innovation value chain supporting proposition P1.

Based on the summarised positions along the innovation value chains of the four bacteria strains, companies' different strategic types (Bröring and Cloutier, 2008) can be identified (Table 2).

Within the food and agricultural sector the two strategic types of 'technology-intense product developer' and 'product developer using existing technologies' can be found. The companies in the pharmaceutical sector show the 'product developer using existing technologies' strategic type as well as the 'technology developer' strategic type. The research

Table 2. Categorisation of strategic types based on company's position along the probiotics innovation value chain.

\begin{tabular}{|c|c|c|c|c|c|}
\hline \multirow[t]{2}{*}{ Industrial background } & \multirow[t]{2}{*}{ Coding } & \multicolumn{3}{|c|}{ Position in the value chain } & \multirow[t]{2}{*}{ Identified strategic types } \\
\hline & & 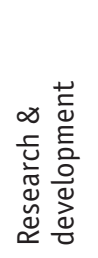 & 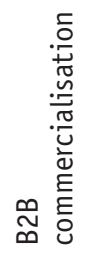 & 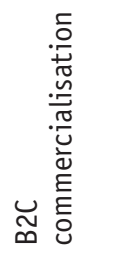 & \\
\hline \multirow{5}{*}{ Food and agriculture } & $1-1$ & $x$ & - & $x$ & b. Technology-intense product developer \\
\hline & $1-2$ & $\mathrm{x}$ & - & $x$ & b. Technology-intense product developer \\
\hline & $1-3$ & - & - & $x$ & c. Product developer using existing technologies \\
\hline & $1-4$ & $x$ & - & $x$ & b. Technology-intense product developer \\
\hline & $1-5$ & - & - & $x$ & c. Product developer using existing technologies \\
\hline \multirow[t]{5}{*}{ Pharmaceutics } & $2-1$ & - & $\mathrm{x}$ & $x$ & c. Product developer using existing technologies \\
\hline & $2-2$ & - & - & $x$ & c. Product developer using existing technologies \\
\hline & $2-3$ & $x$ & - & - & a. Technology developer \\
\hline & $2-4$ & $x$ & - & - & a. Technology developer \\
\hline & $2-5$ & - & - & $x$ & c. Product developer using existing technologies \\
\hline Chemistry & $3-1$ & $x$ & $x$ & - & a. Technology developer \\
\hline Personal care & 4-1 & $x$ & - & - & a. Technology developer \\
\hline Research organisation & $5-1$ & $x$ & - & - & a. Technology developer \\
\hline
\end{tabular}


organisation as well as the chemical and personal care company show characteristics of 'technology developers'.

\section{Knowledge convergence}

In general, it can be stated that in the context of industry convergence several of the identified companies are publishing in fields other than their own - in other words, in other subject areas supporting P2. Thereby, the intensity differs between the distinct industry sectors as explained in the following. Regarding scientific publications, we analyse whether these publications are related to industry convergence. Thereby, industry convergence related scientific publications are those publications focussing on other industrial sectors than the one the publishing company comes from.

In general, the activity in knowledge convergence focusing on probiotics of the companies in the food and agricultural sector is highest. Most of these scientific publications are related to industry convergence as they focus on the pharmaceutical sector. Two companies from the food and agricultural sector $(1-3 ; 1-5)$, the research organisation and the companies from the pharmaceutical sector are not active in scientific publications. Furthermore, there are also scientific publications published by companies from the food and agricultural as well as chemical sector, which focus on more than one subject area. These publications as such show knowledge convergence, as research from the publishing company must be done in an area of industry different from their own. The results regarding the scientific publications of the identified companies support P2 and are shown in Figure 7. Thereby, the number is the absolute number of scientific publications in a specific subject and the percentage value shows the percentage of scientific publications in the respective subject area. The same applies to Figure 8-11.

\section{Technological convergence}

Regarding technological convergence, we analyse whether the patents are related to industry convergence. Thereby, industry convergence related patents are those focussing on other industry sectors than the one in which the patenting company is active. As shown in Figure 8, in general the patenting activity focusing on probiotics of the companies in the food and agricultural sector is highest. Most of the patents that are industry convergence related focus on the pharmaceutical sector. The companies from the pharmaceutical sector are not active in patents. Furthermore, there are patents focussing on more than one subject area, thus showing industry convergence. These results support proposition P3.

Moreover, there are differences in the publishing and patenting behaviour. Based on the higher number of industry convergence related scientific publications than patents, publishing in a research area other than your own seems to be more likely than patenting in other areas in the case of probiotics.

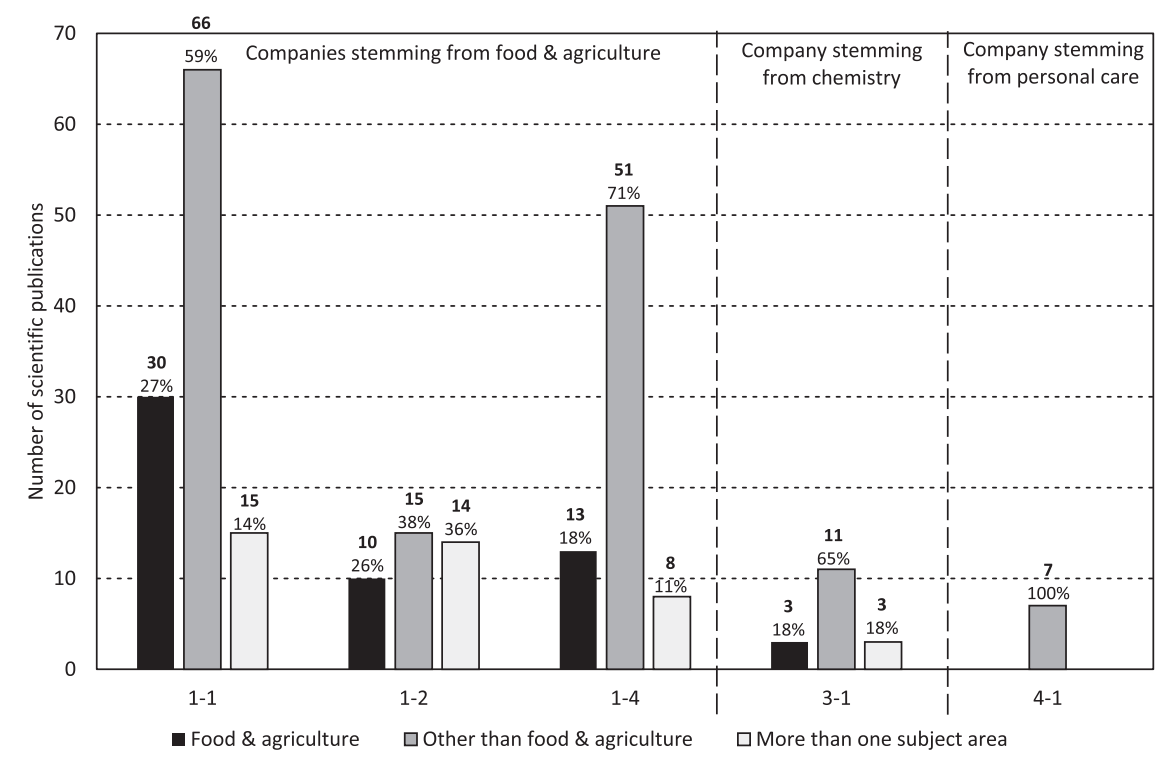

Figure 7. Scientific publications as a function of the publishing company as well as the publication's subject area. 


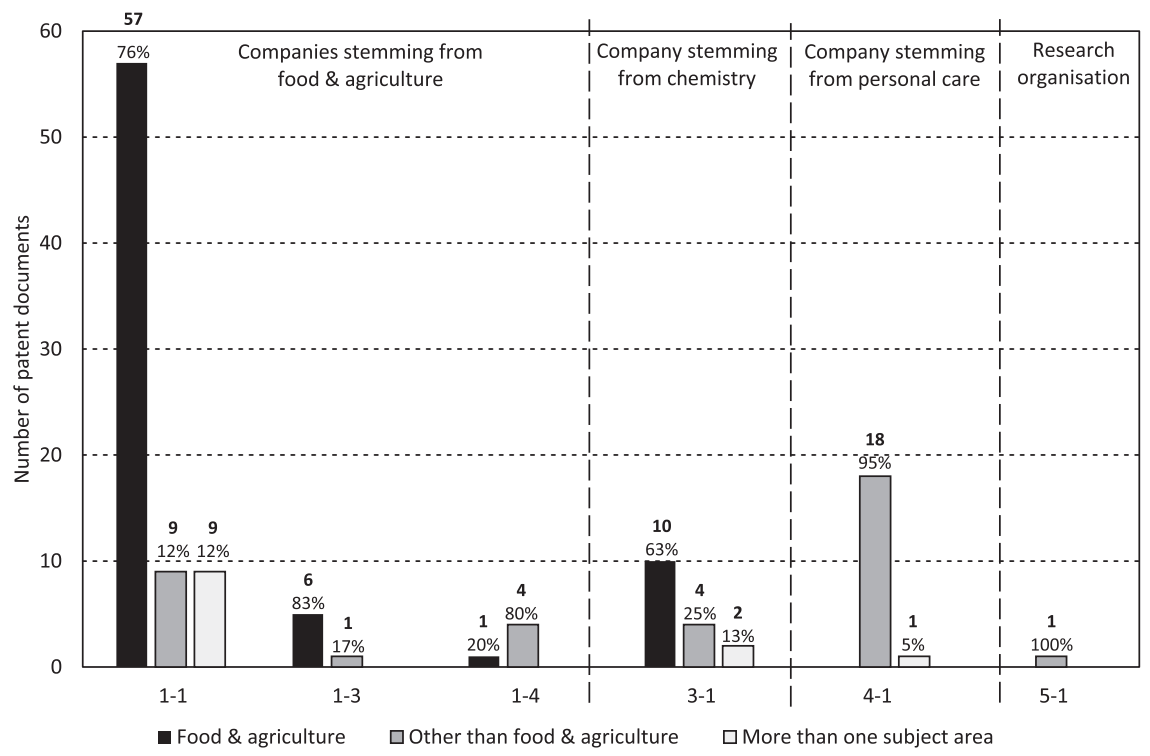

Figure 8. Patent documents as a function of the publishing company as well as the publication's subject area.

\section{Regulatory convergence}

The activity of applying the health claim regulation is highest among the companies stemming from the food and agricultural sector (Table 3 ). The identified health claim activities include the submission, withdrawal and resubmission of health claim applications. Collaborative health claim submissions are those that are jointly submitted by two distinct companies. Those joint applications are identified for three cases in the food and agricultural, chemical and personal care sector. Concurrently, the companies involved in those joint submissions are from distinct industrial backgrounds. Thereby, one collaborative health claim submission is among 1-1 (food and agriculture) and 4-1 (personal care).

Considering the health claim submissions, it can be stated that those companies active in applications are all applying for probiotics health claims, but activities for other health ingredients like prebiotics or peptides can be also shown. These results support $\mathrm{P} 4$.

\section{Competence convergence}

Regarding the measure of mergers and acquisitions, it seems important to consider the position of the company in question as buyer or seller. As industry convergence related mergers and acquisitions focus on the acquirement of external assets, in the present study we consider only those activities in which the analysed company is in the
Table 3. Overview of companies' activities in applying for probiotic health claims.

\begin{tabular}{|c|c|c|c|}
\hline $\begin{array}{l}\text { Industrial background } \\
\text { of company }\end{array}$ & Coding & $\begin{array}{l}\text { Identified } \\
\text { health claim } \\
\text { activities }\end{array}$ & $\begin{array}{l}\text { Collaborative } \\
\text { health claim } \\
\text { activities }\end{array}$ \\
\hline \multirow[t]{6}{*}{ Food \& agriculture } & $1-1$ & 4 & 1 \\
\hline & $1-2$ & 6 & 0 \\
\hline & $1-3$ & 0 & 0 \\
\hline & $1-4$ & 5 & 0 \\
\hline & $1-5$ & 0 & 0 \\
\hline & Sum & 15 & 1 \\
\hline \multirow[t]{6}{*}{ Pharmaceuticals } & $2-1$ & 0 & 0 \\
\hline & $2-2$ & 0 & 0 \\
\hline & $2-3$ & 0 & 0 \\
\hline & $2-4$ & 0 & 0 \\
\hline & $2-5$ & 0 & 0 \\
\hline & Sum & 0 & 0 \\
\hline \multirow[t]{2}{*}{ Chemistry } & $3-1$ & 3 & 1 \\
\hline & Sum & 3 & 1 \\
\hline \multirow[t]{2}{*}{ Personal care } & $4-1$ & 1 & 1 \\
\hline & Sum & 1 & 1 \\
\hline \multirow[t]{2}{*}{ Research organisation } & $5-1$ & 0 & 0 \\
\hline & Sum & 0 & 0 \\
\hline
\end{tabular}


buyer position - therefore, in the following we focus on acquisitions. Furthermore, we analyse whether the acquisitions are related to industry convergence. Thereby, industry convergence related acquisitions are defined as those acquisitions that include the buyer and seller position fulfilled by two different industry sectors.

Acquisition activity is highest among those companies in the food and agricultural sector (Figure 9). With the exception of the companies in the pharmaceutical sector, all companies from the different industrial backgrounds show activity in industry convergence related acquisitions. These results support P5.

Regarding the industry convergence related acquisitions, the companies in the food and agricultural sector focus on the pharmaceutical sector. The chemical company is oriented towards food and agriculture and pharmaceuticals. Considering the industry convergence related acquisitions, the company from the personal care sector concentrates on the pharmaceutical sector.

Regarding the measure of licences, it seems important to consider the position of the involved company as licensor or licensee. As industry convergence related licences focus on the acquirement of external assets from other industrial backgrounds, in the present study we consider only those activities in which the analysed company is in the licensee position. Industry convergence related licences are defined as such when the companies involved come from distinct industrial backgrounds.

The number of licensees is highest among those companies from the food and agricultural sector (Figure 10). In case of the agrifood company 1-1, the licensors are come from the pharmaceutical sector in three cases, showing industry convergence related licences. These results support P5.

Regarding the measure of strategic alliances, acquisitions as well as licences are not considered as these actions are already examined within the two aforementioned measures. Industry convergence related strategic alliances are defined as those where the partners involved have different industrial backgrounds.

The number of strategic alliances is highest among those companies stemming from the food and agricultural sector (Figure 11). Thereby, in all sectors industry convergence related strategic alliances can be shown through the involvement of distinct industrial backgrounds. These results support P5.

Considering companies' characteristics a relationship can be shown between the company's size (sales, employees) and the activity for all industry convergence indicators the higher the sales/number of employees, the higher the activity. For instance, the agrifood company 1-1 shows the highest rates of scientific publications and patents among the identified companies concurrently having the highest

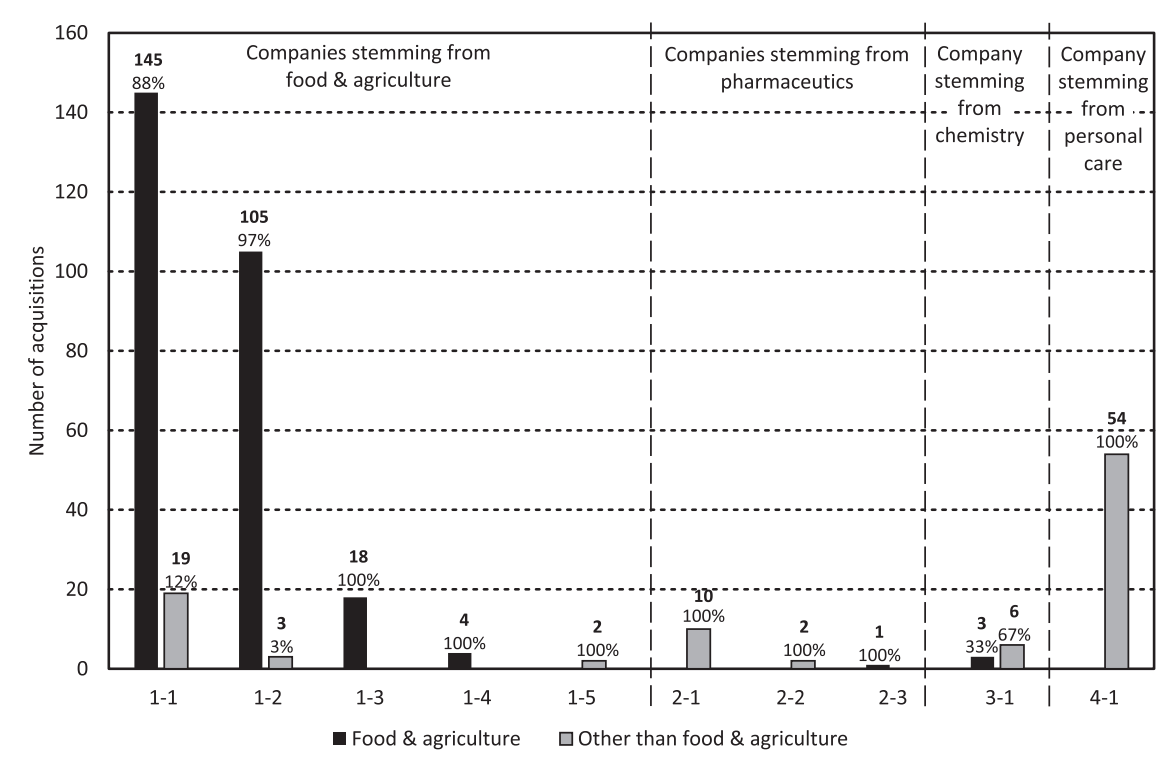

Figure 9. Acquisitions as a function of the buying company as well as the industrial background of the acquired companies. 


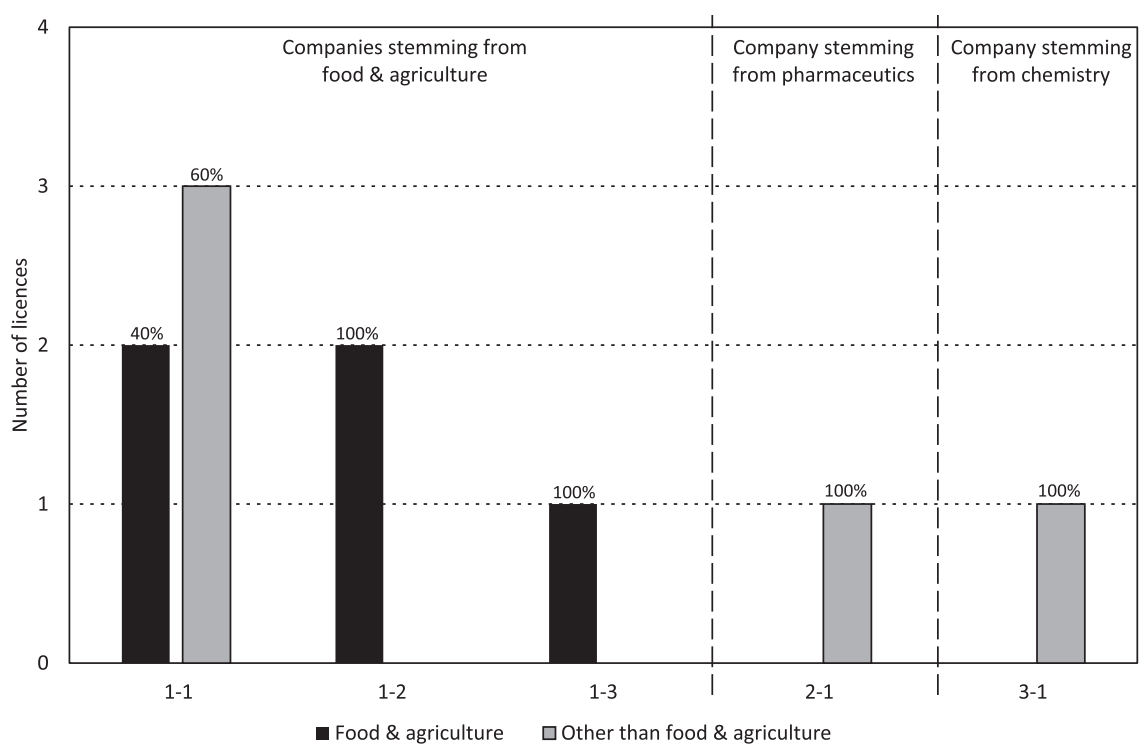

Figure 10. Licences as a function of the industrial background of the licensee and licensor.

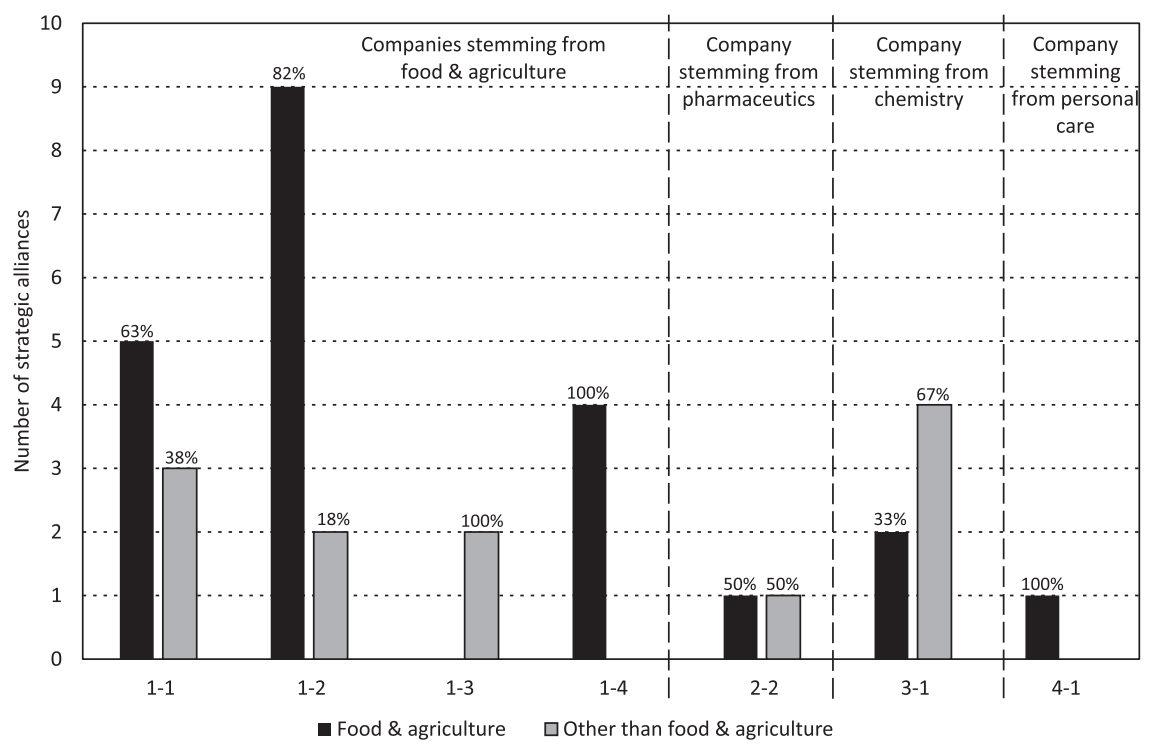

Figure 11. Strategic alliances as a function of the industrial backgrounds of the involved companies.

sales and employees in the sample. This relationship between a company's characteristics and its activity in industry convergence related behaviour might be due to the higher $\mathrm{R} \& \mathrm{D}$ resources of bigger companies which allows companies to spend more on research activities (knowledge and technological convergence) or on acquiring external assets (competence convergence).
Summarising the results on the indicators of industry convergence, it can be stated that there are cross-industry relationships along the probiotics innovation value chains supporting proposition P1. Secondly, there are signs of knowledge as well as technological convergence as the companies are publishing and patenting not only in their former industry sector but also in other sectors supporting proposition P2 and P3. Thirdly, companies of the distinct 
industrial backgrounds show activity in obtaining EFSA approved health claims - so the regulation is applied by distinct industry sectors supporting proposition $\mathrm{P} 4$. Furthermore, competence convergence appears, which supports proposition P5.

\section{Discussion and conclusions}

An analysis of cross-industry relationships in a context of industry convergence reveals that companies from distinct industrial backgrounds are active in the area of probiotics differing in their intensity of industry convergence related behaviour shown by the respective indicators. Therefore, we contribute to the existing body of literature by assessing industry convergence from an innovation value chain perspective and combine this with a set of indicators reflecting the intensity of industry convergence. Those indicators have already been used and tested in literature for the description of industry convergence processes but have not yet been used in an overall combined analysis scrutinising the different dimensions of industry convergence. Ongoing industry convergence processes are discussed to lead to reconfiguration of value chains (Wirtz, 2001) as well as the underlying competence basis as companies try to close their emerging competence gaps. Therefore, the derived framework of indicators might serve for a landscape description of on-going industry convergence processes from an innovation value chain perspective.

Regarding the research question about assessing industry convergence, the active companies show signs of industry convergence related activity on all levels in probiotics. Crossindustry relationships occur in all four innovation value chains showing different positions along the innovation value chain (P1). Therefore, it seems that companies try to close the resulting competence gaps at different stages of the innovation value chain - depending on which stage of the innovation value chain the competence gap emerged for the company in question. Furthermore, signs of knowledge and technological convergence can be shown for the different industry sectors involved, demonstrating industry convergence related behaviour in the early phases of an on-going industry convergence process (P2 and P3). As the already converged legislation (health claim regulation) is applied by different industrial sectors, signs of convergence in regulatory compliance can be identified (P4). This leads to the assumption that the communication to consumers through health claims seems to be an important success factor for probiotics. Competence convergence can be shown through different industrial backgrounds participating in acquisitions, licencing agreements and strategic alliances (P5). This might be due to the necessity of closing competence gaps by means of cross-industry relationships in the context of industry convergence.

In summary, the intensity of industry convergence differs firstly in terms of the different industrial backgrounds, and secondly in terms of the different bacteria strains. The five identified companies stemming from the food and agricultural sector show highly relevant industry convergence related behaviour for all indicators. But the chemical company also shows high tendencies. The companies stemming from these two industry sectors seem to push forward the industry convergence process in probiotics as they show a higher intensity of activities related to industry convergence.

Although different indicators serve to describe the different levels of industry convergence, these dimensions are not detached from each other. For instance, technological and market convergence are linked to each other as technology can be developed in-house or acquired externally (Duysters and Hagedoorn, 1998) - so mergers and acquisitions are linked to both the concept of technological and market convergence as companies acquire other companies to close competence gaps on the technological level. The indicator of regulatory convergence is multifaceted as the health claim regulation as such shows convergence in regulation, for example by applying the same standards for different industry sectors. Clinical trials are mostly applied in the pharmaceutical sector to authorise drugs but are now necessary to promote nutritional products claiming a health effect.

Considering the characteristics of distinct strategic types, all three types of (a) technology developers; (b) technologyintense product developers; and (c) product developers using existing technologies (Bröring and Cloutier, 2008) can be identified in the companies analysed in this study. Based on the differences in the innovation value chains originating from industry convergence processes, the characteristics of these different strategic types can be defined as follows (based on the results regarding P1-P5).

The companies follow different strategies to close the competence gaps resulting from the on-going process of industry convergence. On the one hand, technologyintense product developers use all four indicators of industry convergence related behaviour (e.g. the two agrifood companies 1-1 and 1-2). Therefore, they show big expansions on all levels to close their resulting competence gaps. Regarding the innovation value chain perspective, these industry convergence related activities and relationships also reflect the different steps within 
the innovation value chain. Therefore, technology-intense product developers show a high integration of cross-industry activities along the innovation value chain. On the other hand, product developers using existing technologies focus on the market side of possibilities to close their competence gaps without a focus on the technological side (e.g. the two pharmaceutical companies 2-1, 2-2). Therefore, they focus on the commercialisation step within their industry convergence related behaviour as well as their position within the innovation value chain. As they hardly show tendencies of knowledge or technological convergence related behaviour, one can assume that they try to close their competence gaps from a market driven perspective only, with no interest in the underlying technologies. Furthermore, technology developers seem to follow different strategies (e.g. the two pharmaceutical companies 2-3, 2-4). This might be due to the existing competence base in-house which results in distinct specific competence gaps, which needs to be closed differently.

\section{Limitations and future research}

A qualitative approach was taken to establishing the criteria for selecting the companies for this study. Although this approach cannot deliver a holistic view on all active companies in probiotics, we tried to select the global players in this area by choosing the bacteria strains with the highest global market share. Furthermore, the industrial backgrounds of chemistry and personal care are represented by one company for each sector. Therefore, a generalisation for the whole sector is difficult and further studies could include more companies per sector.

The time-frame for the convergence levels differs because of a different sampling strategy but present an overlap adequate enough to support the propositions. Considering regulatory convergence, the search strategy for health claim submissions is based on publicly available news sources as there is no database available showing the health claim applications related to the submitting company. Therefore, the gathered information is dependent on the information strategy of each company as the companies determine what is published about their health claim submissions. The identified companies differ in their characteristics in terms of company size, market share, employees, etc. This might influence industry convergence related behaviour such as mergers and acquisitions, which are more likely for bigger companies. Therefore, future studies could focus on the differences in cross-industry relationships between distinct company types. Based on the framework of the different indicators analysing industry convergence processes, further studies could concentrate on the elaboration of other emerging industry fields. It might be interesting to examine which differences occur comparing the strategic types of industrial sectors in distinct emerging fields.

\section{Acknowledgements}

The authors would like to thank the researchers from TIFN for their support and access to the respective databases and especially Frances Fortuin, Supranee Tangnatthanakrit and Hilde Boschloo from Wageningen University.

\section{References}

Borés, C., C. Saurina and R. Torres, 2003. Technological convergence. a strategic perspective. Technovation, 23(1): 1-13.

Bornkessel, S., S. Bröring and O. Omta, 2012. Analysing industry convergence in probiotics. In: $10^{\text {th }}$ Wageningen International Conference on Chain and Network Management. May 23-25, 2010. Wageningen, the Netherlands.

Bornkessel, S., C.-S. Curran, S. Bröring and O. Omta, 2011. Who is leading the way? Different dynamics of converging industries in nutraceuticals and functional foods. ISPIM, Hamburg, Germany.

Boschloo, H., 2011. Probiotics: from patent to consumer product - a dairy case. Wageningen University, Wageningen, the Netherlands.

Bower, J.L., 2001. Not all M\&As are alike - and that matters. Harvard Business Review, 79(3): 92-103.

Bröring, S., 2005. The front end of innovation in converging industries. The case of nutraceuticals and functional foods. Dt. Univ.-Verl., Wiesbaden, Germany, 342 pp.

Bröring, S. and L.M. Cloutier, 2008. Value-creation in new product development within converging value chains. An analysis in the functional foods and nutraceutical industry. British Food Journal, 110(1): 76-97.

Bröring, S., L.M. Cloutier and J. Leker, 2006. The front end of innovation in an era of industry convergence: evidence from nutraceuticals and functional foods. R\&D Management, 36(5): 487-498.

Bröring, S. and J. Leker, 2007. Industry convergence and its implications for the front end of innovation: a problem of absorptive capacity. Creativity and innovation management, 16(2): 165-175.

Curran, C.S. (ed.), 2010. The anticipation of converging industries - a concept applied to nutraceuticals and functional foods. Westfälische Wilhelms-Universität Münster, Münster, Germany.

Curran, C.S., S. Bröring and J. Leker, 2010. Anticipating converging industries using publicly available data. Technological Forecasting \& Social Change, 77(3): 385-395.

Daim, T.U., G. Rueda, H. Martin and P. Gerdsri, 2006. Forecasting emerging technologies: use of bibliometrics and patent analysis. Technological Forecasting \& Social Change, 73(8): 981-1012. 
Duysters, G. and J. Hagedoorn, 1998. Technological convergence in the IT industry. The role role of strategic technology alliances and technological competencies. The Internationalisation of the Innovation Process, 5(3): 355-368.

European Commission (EC), 2006. Regulation (EC) no 1924/2006 of the European Parliament and of the Council of 20 December 2006 on nutrition and health claims made on foods. Official Journal of the European Union L 404: 9. Available at: http:// tinyurl.com/l3tuyhl.

Enkel, E. and O. Gassmann, 2010. Creative imitation: exploring the case of cross-industry innovation. R \& D Management, 40(3): 256-271.

Ernst, H., 1998. Patent portfolios for strategic R\&D planning. Journal of Engineering and Technology Management, 15(4): 279-308.

Fai, F. and N. von Tunzelmann, 2001. Industry-specific competencies and converging technological systems: evidence from patents. Structural change and economic dynamics, 12(2): 141-170.

Falkner, R. and A. Gupta, 2009. The limits of regulatory convergence: globalization and GMO politics in the south. International Environmental Agreements: Politics, Law and Economics, 9(2): 113-134.

Farber, D. and P. Baran, 1977. The convergence of computing and telecommunications systems. Science, 195(4283): 1166-1170.

Gambardella, A. and S. Torrisi, 1998. Does technological convergence imply convergence in markets? Evidence from the electronics industry. Technology and The Firm, 27(5): 445-463.

Giuri, P., M. Mariani, S. Brusoni, G. Crespi, D. Francoz, A. Gambardella, W. Garcia-Fontes, A. Geuna, R. Gonzales, D. Harhoff, K. Hoisl, C. Le Bas, A. Luzzi, L. Magazzini, L. Nesta, Ö. Nomaler, N. Palomeras, P. Patel and M. Romanelli, 2007. Inventors and invention processes in Europe: results from the PatVal-EU survey. Research Policy, 36(8): 1107-1127.

Guilhon, B., 2001. Technology and markets for knowledge. Knowledge creation, diffusion and exchange within a growing economy. Economics of Science, Technology and Innovation no. 22, Springer, Boston, MA, USA.

Hacklin, F. (ed.), 2008. Management of convergence in innovation - strategies and capabilities for value creation beyond blurring industry boundaries. Physica-Verlag, Heidelberg, Germany.

Hansen, M.T. and J. Birkinshaw, 2007. The innovation value chain. Harvard Business Review, 85(6): 121-130.

Henderson, R.M. and K.B. Clark, 1990. Architectural innovation: the reconfiguration of existing product technologies and the failure of established firms. Administrative Science Quarterly, 35(1): 9-30.

Johnson, R.B. and A.J. Onwuegbuzie, 2004. Mixed methods research: a research paradigm whose time has come. Educational researcher, 33(7): 14-26.

Kaplinsky, R. and M. Morris, 2000. A handbook for value chain research. Available at: www.prism.uct.ac.za/papers/vchnov01.pdf.
Katz, M.L., 1996. Remarks on the economic implications of convergence. Industrial and Corporate Change, 5(4): 1079-1095.

Kim, M.-S. and C. Kim, 2012. On a patent analysis method for technological convergence. Procedia - Social and Behavioral Sciences, 40: 657-663.

Latcheva, R., 2011. Cognitive interviewing and factor-analytic techniques: a mixed method approach to validity of survey items measuring national identity. Quality \& Quantity, 45(6): 1175-1200.

Liu, S.J. and J. Shyu, 1997. Strategic planning for technology development with patent analysis. International journal of technology management, 13(5-6): 661-680.

Malhorta, A. and A.K. Gupta, 2001. An investigation of firm's strategic response to industry convergence. Academy of Mangement Proceedings - Best Paper Series: G1.

Nyström, A.-G., 2008. Understanding change processes in business networks. a study of convergence in Finnish telecommunications 1985-2005. Åbo Akademi, Åbo, Finland, pp. 273.

Organisation for Economic Co-operation and Development (OECD), 1992. Telecommunications and broadcasting: convergence or collision? OECD, Paris, France.

Pennings, J.M. and P. Puranam, 2001. Market convergence \& firm strategy: new directions for theory and research. In: ECIS Conference, The Future of Innovation Studies. September 20-23, 2001. Eindhoven, the Netherlands.

Prahalad, C.K., 1998. Managing discontinuities: the emerging challenges. Research Technology Management, 41(3): 14-23.

Rosenberg, N., 1976. Perspectives on technology. Cambridge University Press, Cambridge, UK, 354 pp.

Siezen, R.J. and G. Wilson, 2010. Probiotics genomics. Microbial Biotechnology, 3(1): 1-9.

Stanton, C., G. Gardiner, H. Meehan, K. Collins, G. Fitzgerald, P.B. Lynch and R.P. Ross, 2001. Market potential for probiotics. The American Journal of Clinical Nutrition, 73: 476-783.

Stieglitz, N., 2002. Industry dynamics and types of market convergence - the evolution of the handheld computers market in the 1990s and beyond. DRUID Summer Conference on 'Industrial Dynamics of the New and Old Economy - who is embracing whom?', Copenhagen/Elsinore, Denmark. Available at: www.druid.dk/uploads/tx_picturedb/ds2002-651.pdf.

U.S. Securities and Exchange Commission, 2011. Standard Industrial Classification (SIC) Code List. Securities and Exchange Commission, Washington, DC, USA. Available at: www.sec.gov/ info/edgar/siccodes.htm.

Verhagen, H., E. Vos, S. Francl, M. Heinonen and H. Van Loveren, 2010. Status of nutrition and health claims in Europe. Archives of Biochemistry and Biophysics, 501(1): 6-15.

Wirtz, B.W., 2001. Reconfiguration of value chains in converging media and communications markets. Long Range Planning, 34(4): 489-506.

Yoffie, D.B., 1997. Competing in the age of digital convergence. Harvard Business School Press, Boston, MA, USA, 464 pp. 
